\title{
Novel Serum Biomarkers to Differentiate Cholangiocarcinoma from Benign Biliary Tract Diseases Using a Proteomic Approach
}

\author{
Tavan Janvilisri, ${ }^{1}$ Kawin Leelawat, ${ }^{2}$ Sittiruk Roytrakul, ${ }^{3}$ \\ Atchara Paemanee, ${ }^{3}$ and Rutaiwan Tohtong ${ }^{1}$ \\ ${ }^{1}$ Department of Biochemistry, Faculty of Science, Mahidol University, 272 Rama VI Road, \\ Phayathai, Rajdhevi, Bangkok 10400, Thailand \\ ${ }^{2}$ Department of Surgery, Rajavithi Hospital, Bangkok 10400, Thailand \\ ${ }^{3}$ Proteomics Research Laboratory, Genome Institute, National Center for Genetic Engineering and Biotechnology, \\ NSTDA, Pathumthani 12120, Thailand \\ Correspondence should be addressed to Rutaiwan Tohtong; rutaiwan.toh@mahidol.ac.th
}

Received 20 August 2014; Accepted 13 October 2014

Academic Editor: Joy Scaria

Copyright (C) 2015 Tavan Janvilisri et al. This is an open access article distributed under the Creative Commons Attribution License, which permits unrestricted use, distribution, and reproduction in any medium, provided the original work is properly cited.

Background and Aim. Cholangiocarcinoma (CCA) is the most frequent biliary malignancy, which poses high mortality rate due to lack of early detection. Hence, most CCA cases are present at the advanced to late stages with local or distant metastasis at the time of diagnosis. Currently available tumor markers including CA19-9 and CEA are inefficient and of limited usage due to low sensitivity and specificity. Here, we attempt to identify serum tumor markers for CCA that can effectively distinguish CCA from benign biliary tract diseases (BBTDs). Methods. Serum samples from 19 CCA patients and 17 BBTDs were separated by SDS-PAGE followed with LC-MS/MS and were subjected to statistical analysis and cross-validation to identify proteins whose abundance was significantly elevated or suppressed in CCA samples compared to BBTDs. Results. In addition to identifying several proteins previously known to be differentially expressed in CCA and BBTDs, we also discovered a number of molecules that were previously not associated with CCA. These included FAM19A5, MAGED4B, KIAA0321, RBAK, and UPF3B. Conclusions. Novel serum biomarkers to distinguish CCA from BBTDs were identified using a proteomic approach. Further validation of these proteins has the potential to provide a biomarker for differentiating CCA from BBTDs.

\section{Introduction}

Cholangiocarcinoma (CCA) is one of the highly aggressive malignant tumors that arise from the cholangiocytes lining biliary trees [1]. The incidence and mortality of the disease continue to increase worldwide, and the highest incidence has been observed in the Southeast Asia, especially in Thailand $[2,3]$. The prognosis of this malignancy is poor due to its silent clinical characteristics, difficulties in early diagnosis, and limited therapeutic measures. At present, radiotherapy and chemotherapy do not significantly improve the survival rate, while the resection of detected tumors at the early stage offers the best curative treatment [4]. Clinical presentations of most CCA patients include biliary tract obstruction; however, many cases of benign biliary tract diseases (BBTDs) are also presented with similar clinical symptoms [5]. Differences in the treatment and prognosis between CCA and BBTDs urge us a need to identify accurate tumor biomarkers that can differentially diagnose the CCA from BBTDs. As CCA typically grows along the bile duct without protruding outward as a forming mass, therefore current imaging techniques including ultrasound, computed tomography (CT), and magnetic resonance imaging (MRI) are not efficient to reveal this lesion [6]. Laboratory assessments for CCA are often not sensitive, nor specific enough. Distinguishing between benign and malignant causes of biliary tract obstruction based on biopsies is rather difficult and usually inadequate to provide an accurate measure. Currently, determination of the serum marker carbohydrate antigen 19-9 (CA19-9) concentration is routinely applied in most laboratories for 
CCA detection. However, a wide range of sensitivity (5090\%) and specificity (54-98\%) of this biomarker for CAA has been reported [7-9], and the elevated serum CA19-9 has also been observed in patients with BBTDs [10, 11]; therefore, the use of CA19-9 for differentiating CCA and BBTDs is not reliable. Other serum markers including carcinoembryogenic antigen (CEA) and cancer antigen 125 (CA125) have also been used for detecting CCA, but these markers are not satisfactory for CCA detection due to low specificity and sensitivity for screening [12-14]. Hence, identification of new tumor markers in the serum would be beneficial in the clinical management of this disease.

In recent years, quantitative proteomics has gained considerable attention and investment in order to identify diagnostic biomarkers for several diseases, including a variety of cancers [15]. In the present study, the proteome of serum samples from CCA patients were quantitatively compared with that of patients with BBTDs, who have shared many molecular and imaging features with CCA. A large-scale quantitative global protein profiling of serum coupled with bioinformatic analyses would identify a proteomic signature for effectively differentiating CCA from BBTDs. Patterns of differentially serum protein expression between CCA and BBTD patients were exploited for development of diagnostic or prognostic tool for this type of cancer.

\section{Methods}

2.1. Serum Samples. Serum samples were collected from obstructive jaundice patients who underwent endoscopic retrograde cholangiography (ERCP) or biliary tract surgery at Rajavithi Hospital. The use of human materials was approved by the research ethics committee of Rajavithi Hospital. Seventeen patients with BBTDs and 19 CCA patients were enrolled in this study. The diagnosis of CCA was carried out using one of the following criteria: (i) tissue biopsy; (ii) cytology plus radiological (CT scan or MRI) and clinical observation to identify tumor progression at a follow-up of at least two months. Serum samples from these patients were separated by centrifugation and stored at $-80^{\circ} \mathrm{C}$ within $1 \mathrm{~h}$. The biochemical determinations of serum markers, including CEA and CA19-9, were performed using routine automated methods in the Pathological Laboratory at Rajavithi Hospital.

2.2. Sample Preparation, Electrophoresis, and Trypsin Digestion. Samples were treated with protease inhibitor cocktail and protein extraction from serum was carried out in lysis buffer containing $8 \mathrm{M}$ urea and $10 \mathrm{mM}$ dithiothreitol (DTT). Protein concentration was determined using Bradford protein assay with bovine serum albumin as a standard. Fifty micrograms of total serum proteins were resolved on $12.5 \%$ SDS-PAGE. The gel was then fixed for $30 \mathrm{~min}$ in a fixing solution containing 50\% methanol, $12 \%$ acetic acid, and $0.05 \%$ formaldehyde, washed twice for $20 \mathrm{~min}$ in $35 \%$ ethanol, and then sensitized in $0.02 \%(\mathrm{w} / \mathrm{v})$ sodium thiosulfate for $2 \mathrm{~min}$ with mild agitation. After washing twice for $5 \mathrm{~min}$ each with deionized water, the gel was then stained with $0.2 \%(\mathrm{w} / \mathrm{v})$ silver nitrate for $20 \mathrm{~min}$ and washed twice prior to the detection in a developing solution $(6 \%(\mathrm{w} / \mathrm{v})$ sodium carbonate, $0.02 \%(\mathrm{w} / \mathrm{v})$ sodium thiosulfate and $0.05 \%$ formalin). The staining was stopped by incubation in $1.5 \% \mathrm{Na}_{2}$ EDTA solution for $20 \mathrm{~min}$. Finally, the stained gel was washed three times for $5 \mathrm{~min}$ each with deionized water. The gel was scanned using a GS-710 scanner (Bio-Rad, Benicia, CA) before being stored in $0.1 \%$ acetic acid until in-gel tryptic digestion.

The gel lanes were divided into 5 fractions according to the standard protein markers and then subdivided into 15 ranges. Each gel range was chopped into pieces $\left(1 \mathrm{~mm}^{3} /\right.$ piece $)$, which were dehydrated in $100 \%$ acetonitrile (ACN) for $5 \mathrm{~min}$ with agitation and dried at room temperature for $15 \mathrm{~min}$. Subsequently, the cysteine residues were blocked with $10 \mathrm{mM}$ DTT in $10 \mathrm{mM} \mathrm{NH}_{4} \mathrm{HCO}_{3}$ for $1 \mathrm{~h}$ at room temperature and alkylated with $100 \mathrm{mM}$ iodoacetamide in $10 \mathrm{mM} \mathrm{NH}_{4} \mathrm{HCO}_{3}$ for $1 \mathrm{~h}$ at room temperature in the dark. The gel pieces were dehydrated twice in $100 \% \mathrm{ACN}$ for $5 \mathrm{~min}$ and then were incubated with $0.20 \mu \mathrm{g}$ trypsin in $50 \% \mathrm{ACN} / 10 \mathrm{mM} \mathrm{NH}_{4} \mathrm{HCO}_{3}$ for $20 \mathrm{~min}$. Purified peptide fractions were dried and reconstituted in $2 \% \mathrm{ACN}$ and $0.1 \%$ formic acid for subsequent LC-MS/MS.

\subsection{Liquid Chromatography-Tandem Mass Spectrometry} (LC/MS-MS). The LC-MS/MS analysis was carried out using a Waters nanoACQUITY ultra performance liquid chromatography coupled with a SYNAPT HDMS mass spectrometer. A 5- $\mu \mathrm{L}$ aliquot of peptide fractions was injected using a builtin nanoACQUITY auto sampler onto a Symmetry C18 trapping column $(200 \mu \mathrm{m} \times 180 \mathrm{~mm}, 5 \mu \mathrm{m}$ particle size; Waters) at $10 \mu \mathrm{L} / \mathrm{min}$ flow rate for on-line desalting and then separated on a C-18 RP nano-BEH column $(75 \mu \mathrm{m}$ id $\times$ $200 \mathrm{~mm}, 1.7 \mu \mathrm{m}$ particle size, Waters) and eluted in a $30 \mathrm{~min}$ gradient of $2 \%$ to $40 \% \mathrm{ACN}$ in $0.1 \%$ formic acid (FA) at $350 \mathrm{~nL} / \mathrm{min}$, followed by a 10 -min ramping to $80 \% \mathrm{ACN}-$ $0.1 \% \mathrm{FA}$ and a 5 -min holding at $80 \% \mathrm{ACN}-0.1 \% \mathrm{FA}$. The column was reequilibrated with $2 \%$ ACN-0.1\% FA for $20 \mathrm{~min}$ prior to the next run. The MS nanoion source contained a $10-\mu \mathrm{m}$ analyte emitter (New Objective, Woburn, MA) and an additional $20-\mu \mathrm{m}$ reference sprayer through which a solution of $200 \mathrm{fmol} / \mu \mathrm{L}$ Glu Fibrinopeptide B (Glufib) in $25 \%$ ACN-0.1\% FA was constantly infused at $200 \mathrm{~nL} / \mathrm{min}$ for external lock mass correction at $30 \mathrm{~s}$ intervals. For all measurements, the MS instrument was operated in $\mathrm{V}$ mode (at 10,000 resolution) with positive nanoES ion mode. The instrument was tuned and calibrated by infusion of $200-\mathrm{fmol} / \mu \mathrm{L}$ Glufib and set up for a spray voltage at $2.7 \mathrm{kV}$ and sample cone voltage at $45 \mathrm{eV}$. The spectral acquisition time was $0.6 \mathrm{sec}$. In MS expression mode, low energy of trap was set at a constant collision energy of $6 \mathrm{~V}$. In elevated energy of MS expression mode, the collision energy of trap was ramped from 15 to $40 \mathrm{~V}$ during each 0.6-s data collection cycle with one complete cycle of low and elevated energy. In transfer collision energy control, $4 \mathrm{~V}$ and $7 \mathrm{~V}$ were set for low and high energy, respectively. The quadrupole mass analyzer was adjusted such that ions from m/z 200 to 1990 were efficiently transmitted. 
TABLE 1: Clinical characteristics of patients with benign biliary tract diseases (BBTDs) and cholangiocarcinoma (CCA) in this study.

\begin{tabular}{lccc}
\hline Characteristics & BBTDs & CCA & $P$ values \\
\hline $\begin{array}{l}\text { Number of patients } \\
\text { Sex }\end{array}$ & 17 & 19 & - \\
$\quad$ (Male : female) & $10: 7$ & $10: 9$ & 0.085 \\
$\begin{array}{l}\text { Age (years) } \\
\quad \text { Mean } \pm \text { S.D. }\end{array}$ & $52.6 \pm 13$ & $60.9 \pm 13$ & 0.285 \\
$\begin{array}{l}\text { CEA (U/mL) } \\
\text { Median } \\
\quad \text { Min-max })\end{array}$ & 8.70 & 9.87 & \\
$\begin{array}{l}\text { CA19-9 (ng/mL) } \\
\text { Median }\end{array}$ & 48.03 & $(1.47-410.40)$ & 0.711 \\
$\quad($ Min-max $)$ & $(0.60-10000)$ & $(0.60-10000)$ & 0.015 \\
\hline
\end{tabular}

2.4. Data Processing, Protein Identification, and Data Analysis. Continuum LC-MS data were processed using ProteinLynx Global Server version 2.4 (Waters) for ion detection, clustering, and mass correction. Protein identification was performed with the embedded ion accounting algorithm against NCBI human protein database with the minimum cutoffs of two peptides/proteins. The relative quantitation ratios were $\log _{2}$-transformed, processed with median normalization for each sample and rank normalization across the data set. The data were subjected to a 6 -fold cross-validation. A differentially expressed (DE) protein was defined as having a $P$ value of $<0.01$, based on $t$-distribution with Welch approximation, in all data sets in the fold validation. The visualization and statistical analyses were performed using the MultiExperiment Viewer $(\mathrm{MeV})$ in the TM4 suite software [16]. Other information including protein categorization and biological function was analyzed according to protein analysis through evolutionary relationships (Panther) protein classification [17]. Known and predicted functional interaction networks of identified proteins were derived from the STRING database version $9.1[18]$.

2.5. Statistical Analysis. Comparisons between the quantitative variables were performed using either the MannWhitney $U$ or Student's $t$-test, where appropriate. Qualitative variables were reported as counts, and comparisons between independent groups were performed using Pearson Chisquared tests. $P$ values of less than 0.05 were considered significant.

\section{Results}

3.1. Patient Characteristics. A total of 36 subjects were included in this serum proteome study, of which 17 were diagnosed as having BBTDs and 19 were diagnosed as having CCA. The BBTD cases included intrahepatic duct stones, common bile duct stones, and benign bile duct strictures. The CCA cases included perihilar cholangiocarcinoma, intrahepatic cholangiocarcinoma, and middle and distal common bile duct cancer. The clinical characteristics of the patients in this study are shown in Table 1 . No statistically significant differences were found among the data of the BBTD patients and

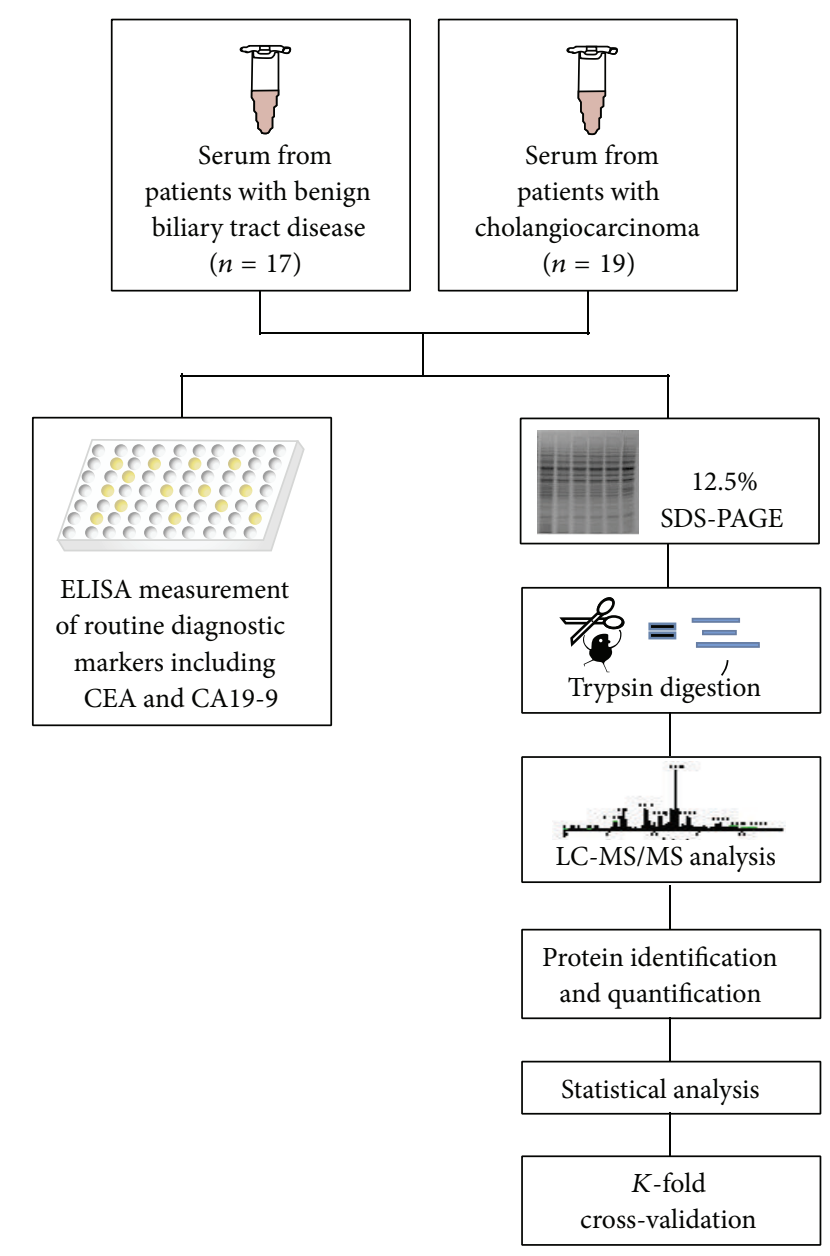

FIGURE 1: Schematic diagram of the experimental workflow. Serum samples were collected from 17 BBTD patients and 19 CCA patients, which were then subjected to routine ELISA for CEA and CA19-9. Purified proteins from these samples were then separated by SDSPAGE. After migration, entire lanes were divided into 5 sections, which were excised into slices and treated with in-gel digestion. The resulting tryptic peptides were subjected to reverse-phase LCMS/MS, from which the mass spectrometric results were then analyzed for protein identification and quantification. The relative quantitation ratios were subjected to statistical analyses and 6-fold cross-validation to retrieve the DE proteins between BBTDs and CCA.

those with CCA regarding gender, age, and CEA. Although the level of CA19-9 in the serum of patients with CCA was significantly higher when compared to the control patients, the range of detection in both groups was exactly the same $(0.60-10000)$.

3.2. Serum Proteome Profiling. An overview of the experimental strategy conducted in this study is shown in Figure 1. The proteome of serum samples from CCA patients was compared with the serum proteome of the BBTD controls in order to identify the proteins in serum, in particular those that are secreted or leaked from tissues including potential differential protein biomarkers from tumor cells. A total of 
TABLE 2: A list of differentially expressed serum proteins between CCA and BBTDs. The protein expression measurements were averaged and represented as $\log _{2}$-transformed intensity values with standard deviation. The $P$ values are also indicated.

\begin{tabular}{|c|c|c|c|c|c|}
\hline Protein names & ID details & GI accession & $\begin{array}{c}\mathrm{CCA} \\
\text { mean } \pm \mathrm{SD}\end{array}$ & $\begin{array}{c}\text { BBTD } \\
\text { mean } \pm \text { SD }\end{array}$ & $P$ values \\
\hline \multicolumn{6}{|l|}{$\mathrm{CCA}>\mathrm{BBTD}$} \\
\hline ABHD11 & Alpha/beta hydrolase domain-containing protein 11 & 23200008 & $1.20 \pm 0.4$ & $0.82 \pm 0.3$ & 0.002 \\
\hline- & $\begin{array}{l}\text { Antioxidized LDL immunoglobulin light chain variable } \\
\text { region }\end{array}$ & 62868476 & $0.88 \pm 0.3$ & $0.55 \pm 0.3$ & 0.004 \\
\hline- & $\begin{array}{l}\text { Chain L, crystal structure of the Fab fragment of } \\
\text { nimotuzumab. An antiepidermal growth factor } \\
\text { receptor antibody }\end{array}$ & 255311843 & $1.93 \pm 0.2$ & $1.72 \pm 0.3$ & 0.010 \\
\hline- & Complement factor $\mathrm{H}$ & 758073 & $-0.86 \pm 0.3$ & $-1.51 \pm 0.5$ & 0.001 \\
\hline COG7 & Conserved oligomeric Golgi complex subunit 7 & 23957690 & $-0.50 \pm 0.4$ & $-1.23 \pm 0.5$ & $<0.001$ \\
\hline DHDDS & Dehydrodolichyl diphosphate synthase & 13177736 & $0.14 \pm 0.6$ & $-0.61 \pm 0.5$ & 0.005 \\
\hline MLH1 & DNA mismatch repair protein & 4557757 & $-0.49 \pm 0.5$ & $-1.00 \pm 0.5$ & 0.004 \\
\hline EIF3J & Eukaryotic translation initiation factor 3 subunit $J$ & 83281438 & $2.40 \pm 0.4$ & $1.95 \pm 0.4$ & 0.002 \\
\hline FAM19A5 & FAM19A5 protein & 71052198 & $0.98 \pm 0.3$ & $-0.69 \pm 0.7$ & $<0.001$ \\
\hline $\mathrm{HBZ}$ & Hemoglobin subunite zeta & 4885397 & $-0.23 \pm 0.3$ & $-0.78 \pm 0.4$ & 0.001 \\
\hline V4-34 & IgG & 2632200 & $0.54 \pm 0.4$ & $0.20 \pm 0.2$ & 0.001 \\
\hline- & Immunoglobulin heavy chain variable region & 37694587 & $1.46 \pm 0.4$ & $0.93 \pm 0.5$ & 0.003 \\
\hline IGK & Immunoglobulin kappa light chain VLJ region & 21669309 & $1.98 \pm 0.3$ & $1.68 \pm 0.1$ & $<0.001$ \\
\hline IL16 & Interleukin 16 & 119619506 & $0.15 \pm 0.4$ & $-0.36 \pm 0.6$ & 0.008 \\
\hline KIAA0321 & KIAA0321 protein & 2224583 & $-0.25 \pm 0.8$ & $-1.70 \pm 0.9$ & 0.002 \\
\hline KIAA0612 & KIAA0612 protein & 34327964 & $-1.17 \pm 0.4$ & $-1.76 \pm 0.5$ & 0.006 \\
\hline KIAA0896 & KIAA0896 protein & 71891755 & $0.18 \pm 0.6$ & $-0.50 \pm 0.6$ & 0.003 \\
\hline MAGED4B & Melanoma-associated antigen D4 & 29337296 & $0.33 \pm 0.3$ & $-1.17 \pm 0.9$ & 0.002 \\
\hline NXF3 & Nuclear RNA export factor 3 & 11545757 & $0.59 \pm 0.4$ & $-0.29 \pm 0.5$ & $<0.001$ \\
\hline PAXBP1 & PAX3- and PAX7-binding protein 1 & 22035565 & $0.64 \pm 0.1$ & $0.39 \pm 0.2$ & 0.001 \\
\hline LOC390791 & Peptidyl-prolyl cis-trans isomerase A-like & 310113085 & $-0.50 \pm 0.3$ & $-1.24 \pm 0.4$ & 0.002 \\
\hline PLEKHO2 & $\begin{array}{l}\text { Pleckstrin homology domain-containing family } \mathrm{O} \\
\text { member } 2\end{array}$ & 33457316 & $-0.29 \pm 0.4$ & $-0.91 \pm 0.4$ & 0.001 \\
\hline PLEKHM2 & PLEKHM2 protein & 26251859 & $-0.46 \pm 0.4$ & $-1.06 \pm 0.5$ & 0.002 \\
\hline RBAK & RB-associated $\mathrm{KRAB}$ zinc finger protein & 13430850 & $0.17 \pm 0.5$ & $-0.96 \pm 0.7$ & $<0.001$ \\
\hline PTPRG & Receptor tyrosine phosphatase gamma & 1263069 & $0.90 \pm 0.3$ & $0.54 \pm 0.2$ & $<0.001$ \\
\hline RPS10 & Ribosomal protein $\mathrm{S} 10$ & 3088338 & $0.99 \pm 0.2$ & $0.67 \pm 0.1$ & $<0.001$ \\
\hline NOB1 & RNA-binding protein NOB1 & 7661532 & $-0.81 \pm 0.4$ & $-1.26 \pm 0.4$ & 0.002 \\
\hline VAT1 & Synaptic vesicle membrane protein VAT-1 & 18379349 & $0.57 \pm 0.4$ & $0.15 \pm 0.3$ & 0.003 \\
\hline TRAC-1 & $\mathrm{T} 3$ receptor-associating cofactor- 1 & 1911770 & $0.12 \pm 0.3$ & $-0.28 \pm 0.2$ & $<0.001$ \\
\hline- & Unnamed protein product & 10433849 & $1.67 \pm 0.5$ & $0.77 \pm 0.3$ & $<0.001$ \\
\hline- & Unnamed protein product & 21752201 & $0.27 \pm 0.2$ & $-0.07 \pm 0.3$ & 0.001 \\
\hline \multicolumn{6}{|l|}{$\mathrm{CCA}<\mathrm{BBTD}$} \\
\hline GCAT & 2-Amino-3-ketobutyrate coenzyme A ligase & 7657118 & $-1.62 \pm 0.5$ & $-1.17 \pm 0.3$ & 0.002 \\
\hline ALB & Albumin & 119626083 & $1.05 \pm 0.3$ & $1.45 \pm 0.3$ & $<0.001$ \\
\hline SERPINA1 & Alpha-1-antitrypsin & 1703025 & $0.84 \pm 0.4$ & $1.24 \pm 0.3$ & $<0.001$ \\
\hline $\mathrm{A} 2 \mathrm{M}$ & Alpha-2-macroglobulin & 177872 & $-0.04 \pm 0.4$ & $0.52 \pm 0.3$ & $<0.001$ \\
\hline AGT & Angiotensinogen & 4261988 & $0.09 \pm 0.6$ & $0.79 \pm 0.2$ & $<0.001$ \\
\hline apo AII & Apolipoprotein & 671882 & $0.04 \pm 0.3$ & $0.31 \pm 0.2$ & 0.003 \\
\hline APOB & Apolipoprotein B-100 & 105990532 & $-1.67 \pm 0.4$ & $-0.86 \pm 0.5$ & $<0.001$ \\
\hline ARID5B & AT-rich interactive domain-containing protein $5 \mathrm{~B}$ & 74136549 & $0.08 \pm 0.5$ & $0.71 \pm 0.7$ & 0.006 \\
\hline BAZ2 & BWSCR2 associated zinc-finger protein BAZ2 & 6002480 & $-0.50 \pm 0.9$ & $0.23 \pm 0.3$ & 0.005 \\
\hline Clorf87 & Clorf87 protein & 27503780 & $-0.91 \pm 0.4$ & $-0.49 \pm 0.3$ & 0.001 \\
\hline
\end{tabular}


TABLE 2: Continued.

\begin{tabular}{|c|c|c|c|c|c|}
\hline Protein names & ID details & GI accession & $\begin{array}{c}\mathrm{CCA} \\
\text { mean } \pm \mathrm{SD}\end{array}$ & $\begin{array}{c}\mathrm{BBTD} \\
\text { mean } \pm \mathrm{SD}\end{array}$ & $P$ values \\
\hline \multirow[b]{2}{*}{ PDEA } & cGMP phosphodiesterase & 2366987 & $0.11 \pm 0.4$ & $0.73 \pm 0.3$ & $<0.001$ \\
\hline & $\begin{array}{l}\text { Chain D, The Nucleosome Containing A Testis-Specific } \\
\text { Histone Variant }\end{array}$ & 296863399 & $-2.56 \pm 0.4$ & $-2.04 \pm 0.5$ & 0.002 \\
\hline $\mathrm{C} 4 \mathrm{~A}$ & Complement C4-A & 476007827 & $-0.81 \pm 0.7$ & $-0.02 \pm 0.3$ & $<0.001$ \\
\hline DCAF15 & DDB1- and CUL4-associated factor 15 & 78486540 & $0.87 \pm 0.4$ & $1.31 \pm 0.2$ & $<0.001$ \\
\hline FN1 & Fibronectin 1 & 53791223 & $-0.98 \pm 0.5$ & $-0.29 \pm 0.4$ & $<0.001$ \\
\hline FLJ00044 & FLJ00044 protein & 10440418 & $-1.02 \pm 0.4$ & $-0.59 \pm 0.2$ & 0.004 \\
\hline FLJ16008 & FLJ16008 protein, isoform CRA_b & 119615716 & $1.79 \pm 0.1$ & $1.94 \pm 0.2$ & 0.006 \\
\hline GNG5 & $\begin{array}{l}\text { Guanine nucleotide-binding protein } \mathrm{G}(\mathrm{I}) / \mathrm{G}(\mathrm{S}) / \mathrm{G}(\mathrm{O}) \\
\text { subunit gamma-5 }\end{array}$ & 4885287 & $0.94 \pm 0.3$ & $1.24 \pm 0.1$ & $<0.001$ \\
\hline hCG_1817987 & hCG1817987 & 119612015 & $-0.09 \pm 0.3$ & $0.36 \pm 0.3$ & $<0.001$ \\
\hline hCG_1981701 & hCG1981701 & 119572460 & $-1.14 \pm 0.5$ & $-0.52 \pm 0.5$ & 0.002 \\
\hline hCG_2008076 & hCG2008076 & 119592316 & $0.05 \pm 0.4$ & $0.42 \pm 0.2$ & 0.012 \\
\hline hCG_2008267 & hCG2008267 & 119592800 & $-0.07 \pm 0.4$ & $0.35 \pm 0.2$ & 0.001 \\
\hline hCG_201157 & hCG201157 & 119576573 & $0.64 \pm 0.3$ & $0.89 \pm 0.3$ & 0.009 \\
\hline hCG_2020343 & hCG2020343 & 119629275 & $-0.95 \pm 0.4$ & $-0.27 \pm 0.4$ & $<0.001$ \\
\hline- & Hypothetical protein & 12224988 & $-1.46 \pm 0.5$ & $-0.90 \pm 0.4$ & $<0.001$ \\
\hline FLJ22688 & Hypothetical protein FLJ22688, isoform CRA_b & 119572924 & $-0.93 \pm 0.6$ & $-0.17 \pm 0.4$ & $<0.001$ \\
\hline LOC286076 & Hypothetical protein LOC286076 & 119602615 & $1.19 \pm 0.4$ & $1.52 \pm 0.2$ & 0.003 \\
\hline \multirow{2}{*}{$\operatorname{Ig} A 1$} & Ig Aalphal Bur & 223099 & $1.84 \pm 0.6$ & $2.28 \pm 0.3$ & 0.006 \\
\hline & Immunoglobulin heavy chain variable region & 37694587 & $1.48 \pm 0.3$ & $1.70 \pm 0.1$ & 0.007 \\
\hline ITIH1 & Interalpha (globulin) inhibitor $\mathrm{H} 1$ & 825681 & $-0.74 \pm 0.4$ & $0.08 \pm 0.6$ & 0.001 \\
\hline ITIH2 & Interalpha (globulin) inhibitor $\mathrm{H} 2$ & 119606784 & $-1.44 \pm 0.5$ & $-0.54 \pm 0.4$ & $<0.001$ \\
\hline KRT1 & Keratin 1 & 11935049 & $-1.12 \pm 0.3$ & $-0.56 \pm 0.4$ & $<0.001$ \\
\hline KRT10 & Keratin-10 & 307086 & $-2.40 \pm 0.5$ & $-1.50 \pm 0.6$ & $<0.001$ \\
\hline KIAA0366 & KIAA0366 protein & 2224673 & $-1.45 \pm 0.4$ & $-0.61 \pm 0.6$ & $<0.001$ \\
\hline KIAA0920 & KIAA0920 protein & 40788986 & $1.05 \pm 0.3$ & $1.37 \pm 0.2$ & $<0.001$ \\
\hline KIAA1234 & KIAA1234 protein & 6330736 & $-0.70 \pm 0.4$ & $-0.38 \pm 0.3$ & 0.007 \\
\hline KIAA1529 & KIAA1529 protein & 7959325 & $1.33 \pm 0.3$ & $2.38 \pm 0.4$ & $<0.001$ \\
\hline MAGEB2 & Melanoma-associated antigen B2 & 222418639 & $-0.48 \pm 0.3$ & $-0.07 \pm 0.4$ & 0.001 \\
\hline MTDH & Metadherin & 119612168 & $-0.45 \pm 0.3$ & $-0.09 \pm 0.3$ & $<0.001$ \\
\hline MUC16 & Mucin-16 & 74716283 & $-0.49 \pm 0.5$ & $0.41 \pm 0.4$ & $<0.001$ \\
\hline MYOT & Myotilin & 5803106 & $-0.41 \pm 0.5$ & $0.30 \pm 0.3$ & $<0.001$ \\
\hline NPTX1 & Neuronal pentraxin 1 & 1438954 & $1.51 \pm 0.3$ & $1.74 \pm 0.2$ & 0.010 \\
\hline PLG & Plasminogen & 38051823 & $1.67 \pm 0.3$ & $2.17 \pm 0.4$ & $<0.001$ \\
\hline GALNT2 & Polypeptide $\mathrm{N}$-acetylgalactosaminyltransferase 2 & 4758412 & $-0.99 \pm 0.3$ & $-0.50 \pm 0.3$ & $<0.001$ \\
\hline FAM83E & Protein FAM83E & 153251792 & $0.70 \pm 0.5$ & $1.33 \pm 0.3$ & 0.006 \\
\hline LOC100131107 & Putative UPF0607 protein ENSP00000383783 & 239741331 & $1.03 \pm 0.7$ & $2.07 \pm 0.7$ & 0.002 \\
\hline $\mathrm{RAB}-\mathrm{R}$ & $\mathrm{RAB}-\mathrm{R}$ protein & 4102709 & $-0.83 \pm 0.4$ & $-0.05 \pm 0.3$ & 0.002 \\
\hline UPF3B & Regulator of nonsense transcripts $3 \mathrm{~B}$ & 18375528 & $-2.17 \pm 0.5$ & $-0.99 \pm 0.6$ & $<0.001$ \\
\hline \multirow{3}{*}{ RIMBP3 } & RIMBP3 protein & 71052030 & $0.07 \pm 0.4$ & $0.69 \pm 0.4$ & $<0.001$ \\
\hline & Suppressor of cytokine signaling 3 & 54695958 & $0.85 \pm 0.4$ & $1.23 \pm 0.2$ & 0.004 \\
\hline & Testis specific kinase-1 & 21886788 & $-1.65 \pm 0.3$ & $-1.07 \pm 0.7$ & 0.005 \\
\hline TTC34 & Tetratricopeptide repeat protein 34 & 239741018 & $-0.54 \pm 0.5$ & $0.34 \pm 0.3$ & $<0.001$ \\
\hline TPO & Thyroid peroxidase & 4680721 & $0.69 \pm 0.4$ & $1.15 \pm 0.2$ & $<0.001$ \\
\hline- & $\begin{array}{l}\text { Ubiquitously transcribed tetratricopeptide repeat } \\
\text { protein Y-linked transcript }\end{array}$ & 148733192 & $-1.43 \pm 0.4$ & $-0.88 \pm 0.5$ & 0.001 \\
\hline
\end{tabular}


TABLE 2: Continued.

\begin{tabular}{|c|c|c|c|c|c|}
\hline Protein names & ID details & GI accession & $\begin{array}{c}\mathrm{CCA} \\
\text { mean } \pm \mathrm{SD}\end{array}$ & $\begin{array}{c}\mathrm{BBTD} \\
\text { mean } \pm \text { SD }\end{array}$ & $P$ values \\
\hline- & Unnamed protein product & 34531956 & $0.84 \pm 0.3$ & $1.17 \pm 0.2$ & $<0.001$ \\
\hline- & Unnamed protein product & 10435479 & $0.76 \pm 0.4$ & $1.15 \pm 0.3$ & 0.003 \\
\hline- & Unnamed protein product & 194384842 & $1.24 \pm 0.3$ & $1.67 \pm 0.2$ & $<0.001$ \\
\hline- & Unnamed protein product & 22760231 & $1.14 \pm 0.5$ & $1.77 \pm 0.3$ & $<0.001$ \\
\hline- & Unnamed protein product & 194381130 & $-2.08 \pm 0.4$ & $-1.34 \pm 0.5$ & $<0.001$ \\
\hline DBP & Vitamin D-binding protein & 455970 & $0.88 \pm 0.5$ & $1.30 \pm 0.3$ & 0.007 \\
\hline ZNF410 & Zinc finger protein 410 & 119601547 & $-0.27 \pm 0.4$ & $0.46 \pm 0.3$ & $<0.001$ \\
\hline ZnF_RBZ & ZIS1 & 4191327 & $0.03 \pm 0.4$ & $0.55 \pm 0.4$ & 0.001 \\
\hline
\end{tabular}

951 proteins were identified in all samples. Among these, the ones with altered expression levels in the serum of CCA patients compared to those of BBTD patients were identified. To reduce the effect of biological and experimental variations and the possibility of false-positive protein identification, 6fold cross-validations were performed. In each fold, BBTD and CCA samples were randomly split into a training set (30 cases with 13-15 BBTD and 15-17 CCA) and an independent validation set (6 cases with 2-4 BBTD and 2-4 CCA). Only proteins identified and quantifiable in all folds in cross-validation were further analyzed, allowing for stringent and sensitive protein identification and quantification of differential proteins.

3.3. Identification of Differentially Expressed Proteins between $C C A$ and BBTDs. Applying a $P$ value cutoff of $<0.01$ yielded a total of 94 candidate proteins, with 32 of them up and 62 down in observed abundance for the serum samples from CCA patients comparing to the BBTD controls (Table 2 and Figure 2(a)). We also tested the discriminatory power of these differentially expressed proteins using unsupervised hierarchical clustering. As shown in Figure 2(c), the spectral counts for these proteins resulted in near complete separation of the CCA cases from the BBTD control cases with only two exceptions where BBTD cases were clustered with the CCA samples. However, the PCA scores plot based on the normalized data of serum samples showed a clear separation between the CCA patients and BBTD controls (Figure 2(b)).

The Panther classification system was used to identify the functional attributes of the 94 potential CCA-selective proteins. The analysis of the abundance of each functional category revealed substantial differences in CCA serum proteome compared to the BBTD serum proteome. The number of each functional class of differentially expressed proteins is schematically depicted in Figure 3. The analysis revealed significant enrichment of proteins related to a number of various biological functions such as cell adhesion molecules, cytoskeletal proteins, defense/immunity proteins, enzymes and the modulators, extracellular matrix proteins, membrane traffic proteins, nucleic acid-binding proteins, receptors, signaling molecules, structural proteins, transcription factors, transfer/carrier proteins, and transporters. To gain an overview of the biological interaction among the identified proteins, we also constructed the protein-protein functional networks using String database (Figure 4). The protein network analysis provides us a clearer view of a complex framework of proteins that might result in the differences in CCA and BBTDs.

To determine the distinguishing performance of the top five differentially expressed proteins in terms of fold-change, the comparison of the averaged $\log _{2}$ folds of family with sequence similarity 19 (chemokine (C-C motif)-like), member A5 (FAM19A5) protein, KIAA0321 protein, melanomaassociated antigen D4 (MAGED4B), RB-associated KRAB zinc finger protein (RBAK), and regulator of nonsense transcripts 3B (UPF3B), between CCA and BBTD cases from all cross-validation cohorts was shown in Figure 5. However, due to the limited resources and the lack of availability of an independent validation set, the diagnostic relevance of such molecules for CCA requires further investigation.

\section{Discussion}

CCA is the second most prevalent primary hepatobiliary malignancy and represents about 3\% of all gastrointestinal cancers [1]. It is associated with inflammatory conditions in the biliary system, and patients with risk factors such as primary sclerosing cholangitis and liver fluke infestations have a higher risk for CCA development [1-3]. The generally late clinical presentation of CCA results in a high mortality. At present, the most commonly studied and routinely used serum biomarkers for detecting CCA include CEA and CA199 [6]. However, they are nonspecific to CCA and can be elevated in the setting of other gastrointestinal malignancies or other benign conditions, such as cholangitis, cirrhosis, and hepatolithiasis [7-14]. Based on the results in this study, both CEA and CA19-9 could not also distinguish the patients with CCA and BBTDs in our sample cohort as both appeared to be nonspecific for either case. Hence, there is an urgent need for new diagnostic targets. In this study, we evaluated the differential proteome in the serum between the BBTD controls and CCA patients and identified potential biomarker panels to aid in the diagnosis of these common liver diseases.

Total proteins were retrieved from the whole serum without the depletion of high abundant proteins due to the fact that additional steps may not help enrich the level of low abundant proteins and may reduce reproducibility from one sample to the others [19]. Among the identified 


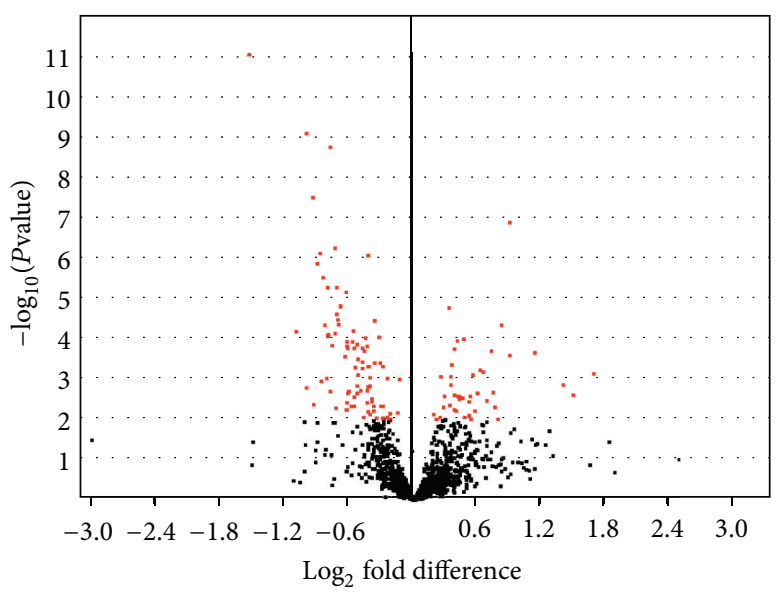

(a)

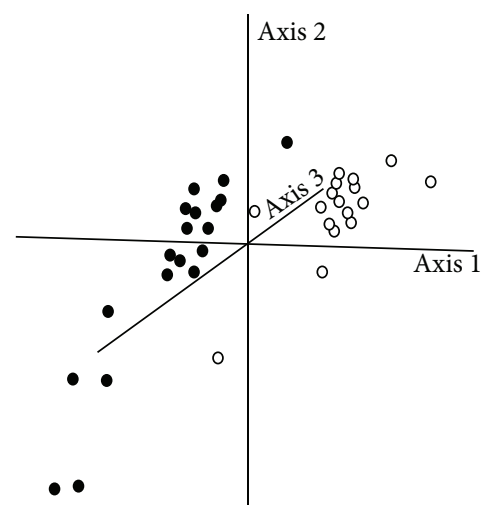

- CCA

O BBTD
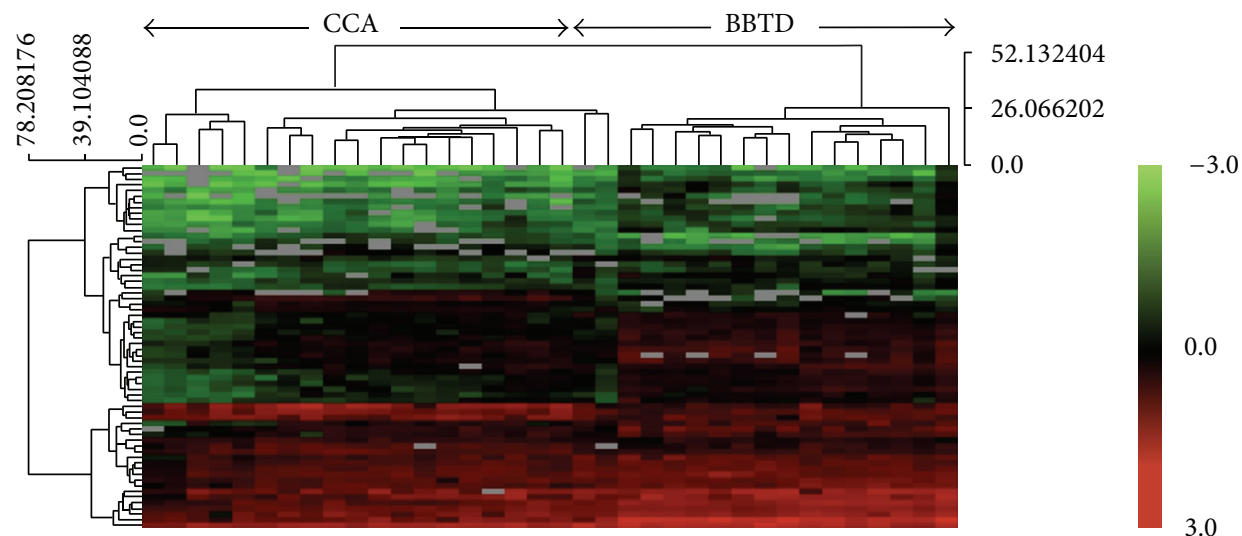

(c)

Figure 2: An overview of the DE proteins between BBTDs and CCA. (a) Volcano plots on $\log _{2}$ fold change and probability values between BBTDs and CCA cases. Red dots correspond to the identified DE proteins that were cut off at $P<0.01$. (b) Principle component analysis for DE proteins. Three-dimensional scatter plot represents two clusters of BBTDs and CCA cases based on the DE proteins. Each dot represents a patient with either BBTDs or CCA, as indicated. (c) A hierarchical clustering analysis was carried out on the basis of the expression pattern. The DE proteins were linked together according to their expression (dendrogram on left). BBTD and CCA patients were also clustered (dendrogram on top). The protein-expression intensities were standardized between -3.0 (green) and 3.0 (red).

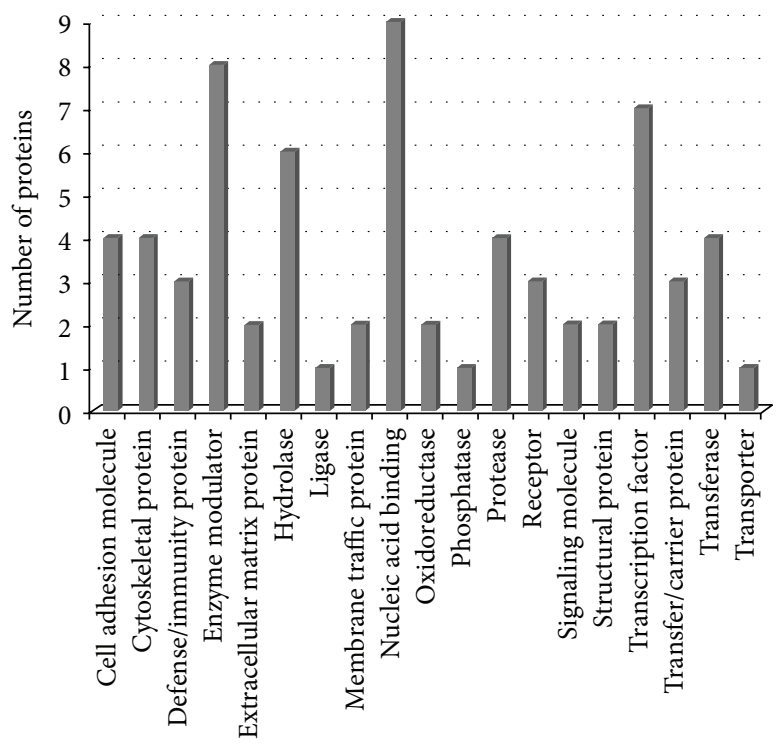

FIGURE 3: Distribution of DE proteins between BBTDs and CCA according to PANTHER protein classes. The bar chart shows the number of DE proteins in each functional class. 


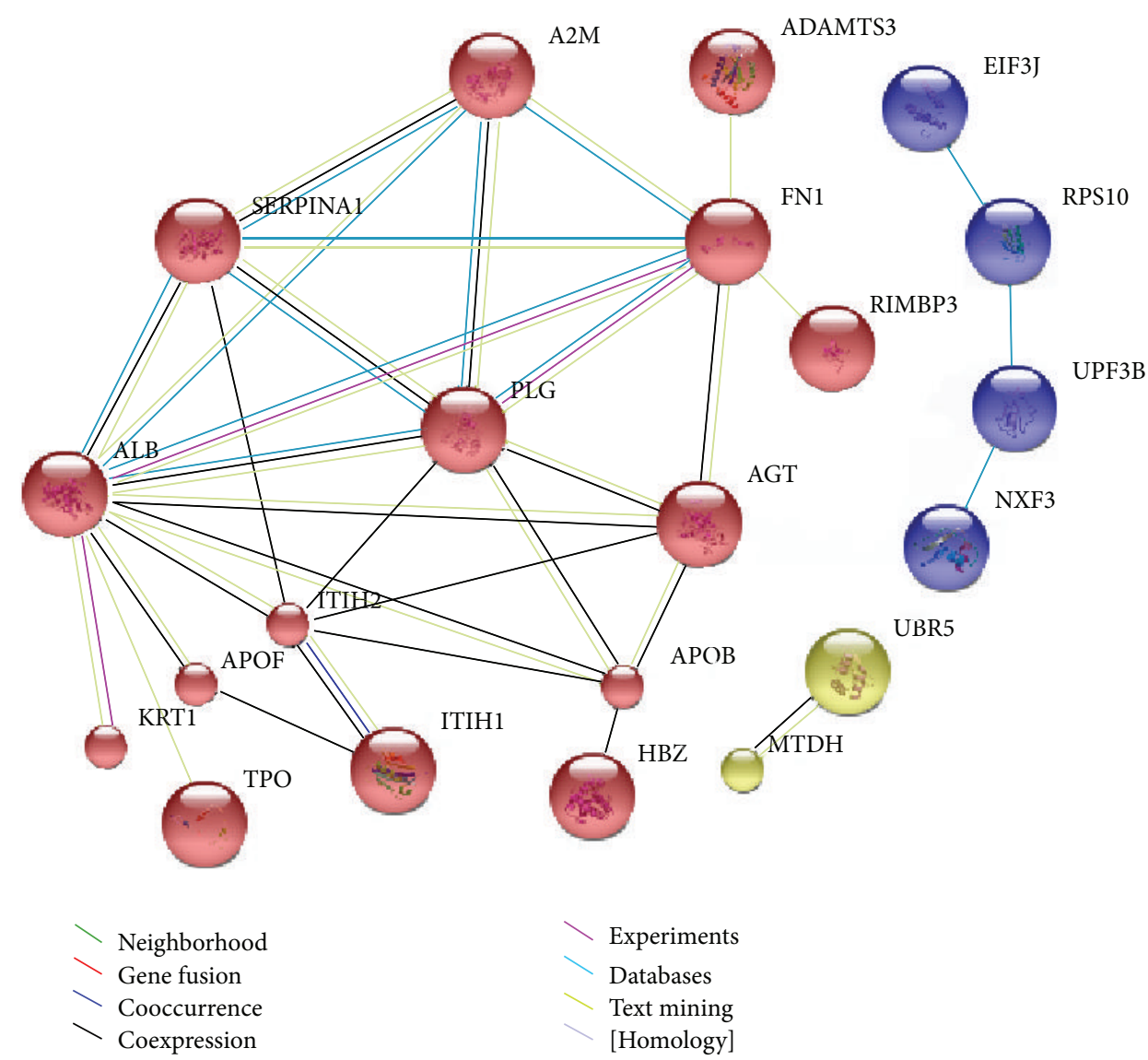

FIGURE 4: Visualization of protein interaction networks of the DE proteins. Inputting all DE proteins into STRING yielded a network visualizing linkages. The network nodes are proteins, whereas the edges represent the functional associations. Different line colors of edges represent different types of evidence for the association, as indicated in the figure.

proteins, we found that a number of them had previously been described in the context of CCA, confirming the validity of our quantitative proteomic approach. These included overexpression of MAGED4 [20] and DNA mismatch repair protein (MLH1) [21, 22], downregulation of albumin (ALB) [20], apolipoprotein B (APOB) [20], apolipoprotein A-II (APOA2) [20], and interalpha (globulin) inhibitor H1 (ITIH1) $[20,23]$. Expression of serum alpha 1-macroglobulin (A2M) was found to be significantly higher in BBTD compared to CCA patients. Consistently, it has also been reported that the serum A2M increased in patients with liver malignancies including CCA but markedly elevated in hepatic cirrhosis [24]. Fibronectin 1 (FN1) in serum of CCA patients seemed to be lower than that of BBTD patients. Biliary FN1 has been reported as a differential biomarker of benign and malignant diseases [25]. Similarly, serum plasminogen (PLG) of CCA cases was significantly lower than that of BBTD controls. PLG in malignant livers including CCA has been demonstrated to be lower than that of the cirrhosis patients [26]. Other serum proteins were also found differentially expressed between CCA and BBTD including angiotensinogen (AGT), ADAM metallopeptidase with thrombospondin type 1 motif 3 (ADAMTS3), hemoglobin, zeta (HBZ), keratin1 (KRT1), keratin-10 (KRT10), and serpin peptidase inhibitor, clade A (alpha-1 antiproteinase, antitrypsin), and member 1 (SERPINA1). However, the validation of these identified proteins is needed in order to determine if they can be clinically useful as differential biomarkers for CCA and BBTD.

The top five proteins which exhibited the maximal fold change between CCA and BBTD consisted of FAM19A5, MAGED4B, KIAA0321, RBAK, and UPF3B. FAM19A5 belongs to the TAFA family of small secreted proteins, which are brain-specific and distantly related to MIP-1 alpha, a member of the CC-chemokine family [27]. This family of proteins has been postulated to function as brain-specific chemokines or neurokines that act as regulators of immune and nervous cells, although the association of this protein and CCA pathogenesis has yet to be evaluated. For MAGED4B, its overexpression has been linked to malignant tumors and poor patient outcome in many types of cancer including breast [28], oral squamous cell carcinoma [29], and hepatocellular carcinoma [30]. However, there are no data available on the expression and the diagnostic or prognostic relevance of MAGED4B in CCA and BBTDs. KIAA0321 is a zinc finger FYVE domain-containing protein, which mediates binding of these proteins to membrane lipids and may be involved in the abscission step of cytokinesis. However, the relevance of 

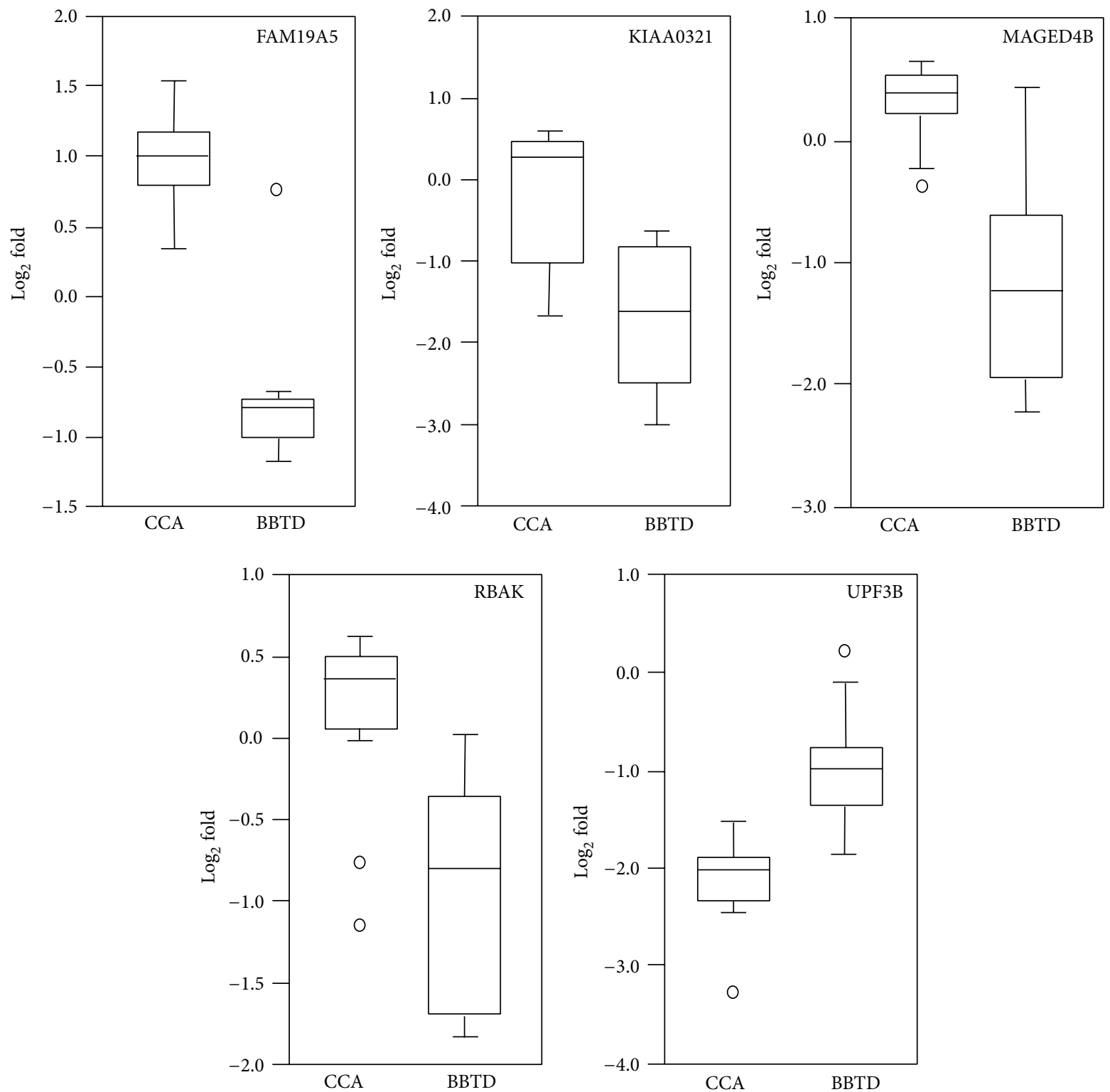

Figure 5: Comparison of the top five differentially expressed proteins between BBTDs and CCA. Normalized $\log _{2}$-transformed data were used to create box plots, in which the horizontal lines of each box correspond to the first, second, and third quartiles (25\%, 50\%, and $75 \%$, resp.) and the whiskers correspond to the maximum and minimum values.

this protein and cancer development is yet to be elucidated [31]. RBAK is a member of a known family of transcriptional repressors that contain zinc fingers of the Kruppel type, which interacts with the tumor suppressor retinoblastoma 1. It has been shown that RBAK is expressed ectopically in human fibroblast cells [32]. Since fibroblasts in the stroma of desmoplastic cancers provide optimal microenvironment for CCA progression and they usually become susceptible for apoptosis [33], it would therefore be possible that overexpression of serum RBAK in CCA patients may be from apoptogenic cancer-associated fibroblasts. UPF3B has been reported to be overexpressed in the patients with alcoholic hepatitis [34], but there is currently no link on UPF3B and cancer yet.

In conclusion we identified proteins in the serum that can potentially discriminate patients with CCA from BBTD individuals through proteomic approach using highly stringent analysis with cross-validation. These proteins will be clinically useful to prevent misdiagnosis between CCA and BBTD as they have similar clinical symptoms. Further independent validation of these biomarkers is certainly required using greater numbers of samples from patients with CCA and a wider range of BBTD conditions to test its robustness and obtain the ones with the greatest diagnostic power for differentiating patients with CCA from BBTD controls. 


\section{Conflict of Interests}

The authors declare that there is no conflict of interests regarding the publication of this paper.

\section{Acknowledgments}

This work was supported by the Faculty of Science, Mahidol University, with funding from a research grant for midcareer university faculty from Thailand Research Fund and Office of the Higher Education Commission (RMU5080066) to RT.

\section{References}

[1] B. Blechacz and G. J. Gores, "Cholangiocarcinoma: advances in pathogenesis, diagnosis, and treatment," Hepatology, vol. 48, no. 1, pp. 308-321, 2008.

[2] Y. Shaib and H. B. El-Serag, "The epidemiology of cholangiocarcinoma," Seminars in Liver Disease, vol. 24, no. 2, pp. 115-125, 2004.

[3] B. Sripa and C. Pairojkul, "Cholangiocarcinoma: lessons from Thailand," Current Opinion in Gastroenterology, vol. 24, no. 3, pp. 349-356, 2008.

[4] T. Nakagohri, T. Kinoshita, M. Konishi, S. Takahashi, and N. Gotohda, "Surgical outcome and prognostic factors in intrahepatic cholangiocarcinoma," World Journal of Surgery, vol. 32, no. 12, pp. 2675-2680, 2008.

[5] F.-T. Deng, Y.-X. Li, L. Ye, L. Tong, X.-P. Yang, and X.-Q. Chai, "Hilar inflammatory pseudotumor mimicking hilar cholangiocarcinoma," Hepatobiliary \& Pancreatic Diseases International, vol. 9, no. 2, pp. 219-221, 2010.

[6] B. E. Van Beers, "Diagnosis of cholangiocarcinoma," $H P B$, vol. 10, no. 2, pp. 87-93, 2008.

[7] A. H. Patel, D. M. Harnois, G. G. Klee, N. F. Larusso, and G. J. Gores, "The utility of CA 19-9 in the diagnoses of cholangiocarcinoma in patients without primary sclerosing cholangitis," The American Journal of Gastroenterology, vol. 95, no. 1, pp. 204-207, 2000.

[8] X.-L. Qin, Z.-R. Wang, J.-S. Shi, M. Lu, L. Wang, and Q.-R. He, "Utility of serum CA19-9 in diagnosis of cholangiocarcinoma: in comparison with CEA," World Journal of Gastroenterology, vol. 10, no. 3, pp. 427-432, 2004.

[9] C. Levy, J. Lymp, P. Angulo, G. J. Gores, N. Larusso, and K. D. Lindor, "The value of serum CA 19-9 in predicting cholangiocarcinomas in patients with primary sclerosing cholangitis," Digestive Diseases and Sciences, vol. 50, no. 9, pp. 1734-1740, 2005.

[10] S. L. Ong, A. Sachdeva, G. Garcea et al., "Elevation of carbohydrate antigen 19.9 in benign hepatobiliary conditions and its correlation with serum bilirubin concentration," Digestive Diseases and Sciences, vol. 53, no. 12, pp. 3213-3217, 2008.

[11] A. Principe, M. Del Gaudio, G. L. Grazi, U. Paolucci, and A. Cavallari, "Mirizzi syndrome with cholecysto-choledocal fistula with a high CA19-9 level mimicking biliary malignancies: a case report," Hepato-Gastroenterology, vol. 50, no. 53, pp. 1259-1262, 2003.

[12] Y. Nakanuma and M. Sasaki, "Expression of blood grouprelated antigens in the intrahepatic biliary tree and hepatocytes in normal livers and various hepatobiliary diseases," Hepatology, vol. 10, no. 2, pp. 174-178, 1989.
[13] A. Nakeeb, P. A. Lipsett, K. D. Lillemoe et al., "Biliary carcinoembryonic antigen levels are a marker for cholangiocarcinoma," The American Journal of Surgery, vol. 171, no. 1, pp. 147152,1996

[14] C.-Y. Chen, S.-C. Shiesh, H.-C. Tsao, and X.-Z. Lin, "The assessment of biliary CA 125, CA 19-9 and CEA in diagnosing cholangiocarcinoma-the influence of sampling time and hepatolithiasis," Hepato-Gastroenterology, vol. 49, no. 45, pp. 616$620,2002$.

[15] Y. Zhao, W.-N. P. Lee, and G. G. Xiao, "Quantitative proteomics and biomarker discovery in human cancer," Expert Review of Proteomics, vol. 6, no. 2, pp. 115-118, 2009.

[16] A. I. Saeed, N. K. Bhagabati, J. C. Braisted et al., "TM4 microarray software suite," Methods in Enzymology, vol. 411, pp. 134-193, 2006.

[17] H. Mi, A. Muruganujan, J. T. Casagrande, and P. D. Thomas, "Large-scale gene function analysis with the PANTHER classification system," Nature Protocols, vol. 8, no. 8, pp. 1551-1566, 2013.

[18] A. Franceschini, D. Szklarczyk, S. Frankild et al., "STRING v9.1: protein-protein interaction networks, with increased coverage and integration," Nucleic Acids Research, vol. 41, pp. D808-D815, 2013.

[19] J. Bruix and J. M. Llovet, "Prognostic prediction and treatment strategy in hepatocellular carcinoma," Hepatology, vol. 35, no. 3, pp. 519-524, 2002.

[20] M.-H. Chen, K.-J. Lin, W.-L. R. Yang et al., "Gene expressionbased chemical genomics identifies heat-shock protein 90 inhibitors as potential therapeutic drugs in cholangiocarcinoma," Cancer, vol. 119, no. 2, pp. 293-303, 2013.

[21] T. Limpaiboon, P. Khaenam, P. Chinnasri et al., "Promoter hypermethylation is a major event of $h M L H 1$ gene inactivation in liver fluke related cholangiocarcinoma," Cancer Letters, vol. 217, no. 2, pp. 213-219, 2005.

[22] U. Liengswangwong, A. Karalak, Y. Morishita et al., "Immunohistochemical expression of mismatch repair genes: a screening tool for predicting mutator phenotype in liver fluke infectionassociated intrahepatic cholangiocarcinoma," World Journal of Gastroenterology, vol. 12, no. 23, pp. 3740-3745, 2006.

[23] I. Subrungruang, C. Thawornkuno, C.-P. Porntip, C. Pairojkul, S. Wongkham, and S. Petmitr, "Gene expression profiling of intrahepatic cholangiocarcinoma," Asian Pacific Journal of Cancer Prevention, vol. 14, no. 1, pp. 557-563, 2013.

[24] S. Changbumrung, P. Migasena, V. Supawan, P. Juttijudata, and T. Buavatana, "Serum protease inhibitors in opisthorchiasis, hepatoma, cholangiocarcinoma, and other liver diseases," The Southeast Asian Journal of Tropical Medicine and Public Health, vol. 19, no. 2, pp. 299-305, 1988.

[25] C.-Y. Chen, X.-Z. Lin, H.-C. Tsao, and S.-C. Shiesh, "The value of biliary fibronectin for diagnosis of cholangiocarcinoma," Hepato-Gastroenterology, vol. 50, no. 52, pp. 924-927, 2003.

[26] H. Alkim, S. Ayaz, N. Sasmaz, P. Oguz, and B. Sahin, "Hemostatic abnormalities in cirrhosis and tumor-related portal vein thrombosis," Clinical and Applied Thrombosis/Hemostasis, vol. 18, no. 4, pp. 409-415, 2012.

[27] Y. T. Tang, P. Emtage, W. D. Funk et al., “TAFA: a novel secreted family with conserved cysteine residues and restricted expression in the brain," Genomics, vol. 83, no. 4, pp. 727-734, 2004.

[28] S. Germano, S. Kennedy, S. Rani et al., "MAGE-D4B is a novel marker of poor prognosis and potential therapeutic target involved in breast cancer tumorigenesis," International Journal of Cancer, vol. 130, no. 9, pp. 1991-2002, 2012. 
[29] C. E. Chong, K. P. Lim, C. P. Gan et al., "Over-expression of MAGED4B increases cell migration and growth in oral squamous cell carcinoma and is associated with poor disease outcome," Cancer Letters, vol. 321, no. 1, pp. 18-26, 2012.

[30] H. Takami, M. Kanda, H. Oya et al., "Evaluation of MAGE-D4 expression in hepatocellular carcinoma in Japanese patients," Journal of Surgical Oncology, vol. 108, no. 8, pp. 557-562, 2013.

[31] T. G. Kutateladze, "Phosphatidylinositol 3-phosphate recognition and membrane docking by the FYVE domain," Biochimica et Biophysica Acta-Molecular and Cell Biology of Lipids, vol. 1761, no. 8, pp. 868-877, 2006.

[32] S. X. Skapek, D. Jansen, T.-F. Wei et al., "Cloning and characterization of a novel Kruppel-associated box family transcriptional repressor that interacts with the retinoblastoma gene product, RB," The Journal of Biological Chemistry, vol. 275, no. 10, pp. 7212-7223, 2000

[33] J. C. Mertens, C. D. Fingas, J. D. Christensen et al., “Therapeutic effects of deleting cancer-associated fibroblasts in cholangiocarcinoma," Cancer Research, vol. 73, no. 2, pp. 897-907, 2013.

[34] S. Affò, M. Dominguez, J. J. Lozano et al., “Transcriptome analysis identifies TNF superfamily receptors as potential therapeutic targets in alcoholic hepatitis," Gut, vol. 62, no. 3, pp. 452-460, 2013. 


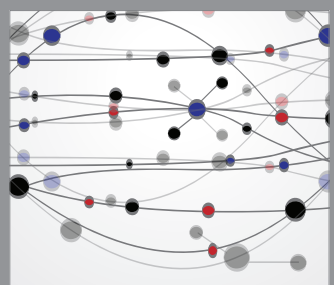

The Scientific World Journal
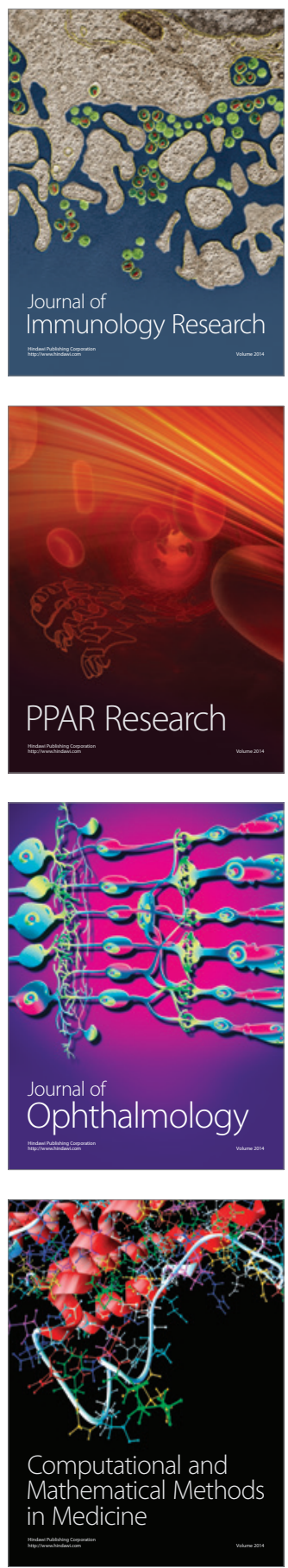

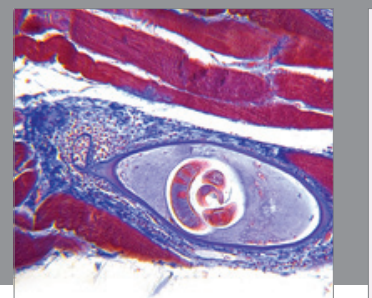

Gastroenterology

Research and Practice
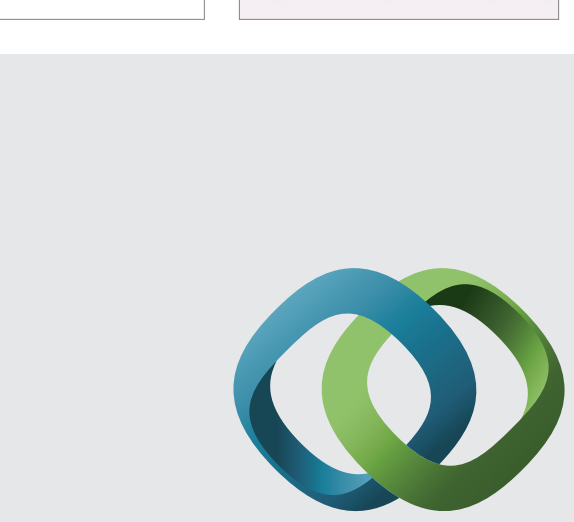

\section{Hindawi}

Submit your manuscripts at

http://www.hindawi.com
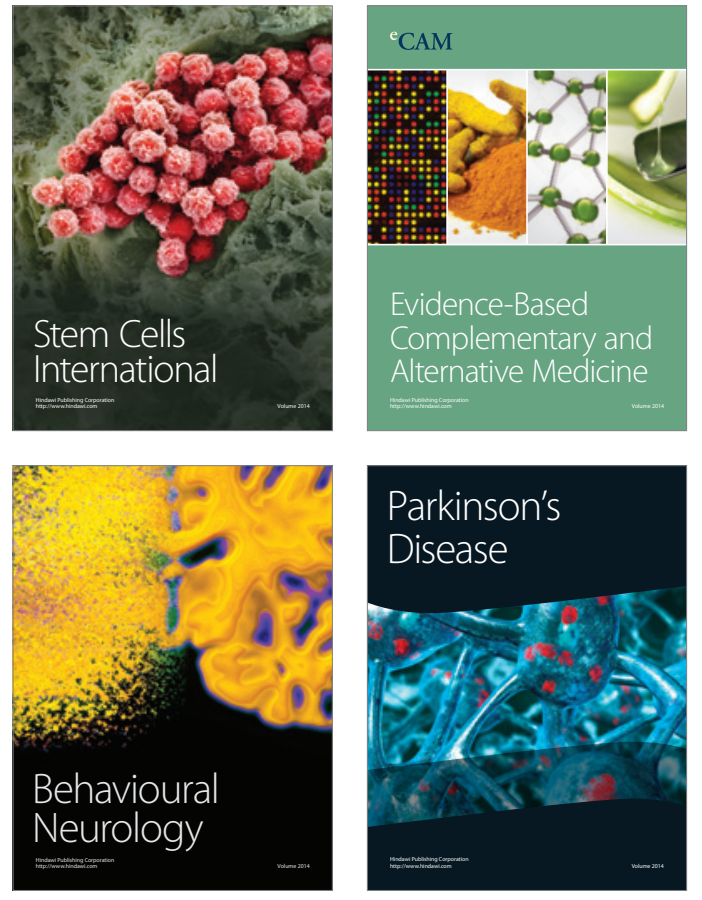
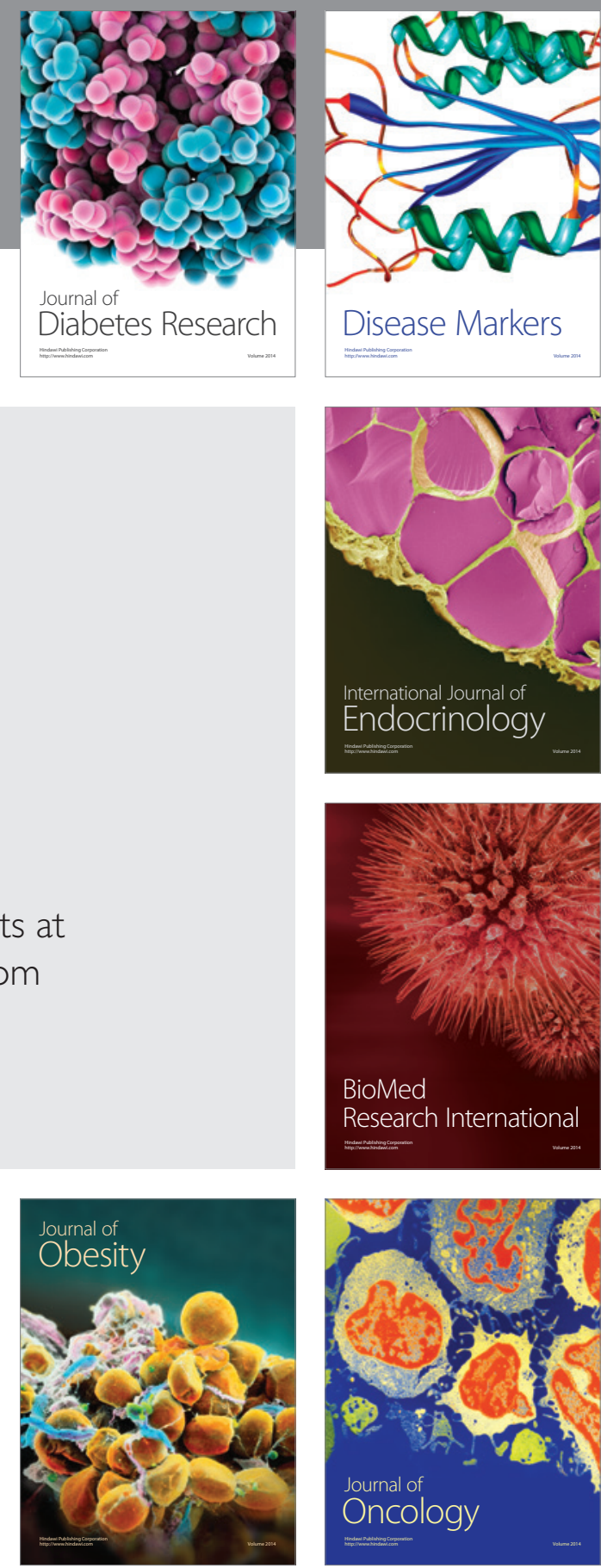

Disease Markers
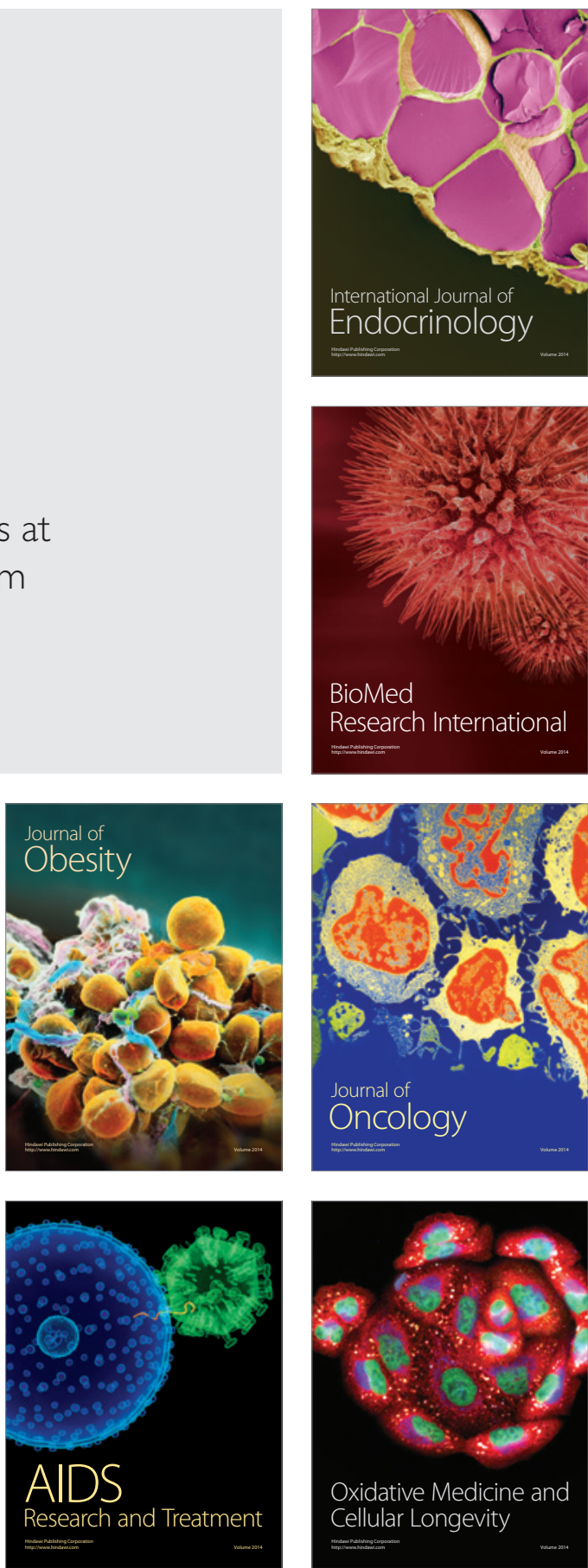